\title{
Chief human resources officers on top management teams: an empirical analysis of contingency, institutional, and homophily antecedents
}

\author{
Magdalena $\mathrm{Abt}^{1} \cdot$ Dodo zu Knyphausen-Aufse $\beta^{1}$
}

Received: 5 June 2015/ Accepted: 13 September 2016/Published online: 21 September 2016

(C) The Author(s) 2016. This article is published with open access at Springerlink.com

\begin{abstract}
Having the director of human resources (HR) as a member of the top management team (TMT) and giving him/her the title of chief human resources officer (CHRO) indicates an important strategic and symbolic choice. Such decisions not only determine who participates in controlling an organization and setting its strategic direction, but also reflect the organizational structure. In this paper, we examine the antecedents of CHRO presence according to the contingency, institutional, and homophily theories. Based on a multi-industry sample of 215 firms that considers a 10-year period, we find that the presence of a CHRO is influenced by the rates of unionization, rapid declines or increases in numbers of employees, the employment of a new or outsider chief executive officer (CEO), and the institutionalization of the CHRO position in the industry or firm. However, we find no evidence of the presumed influence of knowledge intensity or the CEO or TMT human resource management (HRM) experience. Overall, we find that the institutional theory has the highest explanatory power regarding the existence of CHRO positions.
\end{abstract}

Keywords Chief human resources officer - Top management team . Contingency theory $\cdot$ Institutional theory $\cdot$ Homophily theory $\cdot$ Upper echelon theory

Dodo zu Knyphausen-Aufseß

knyphausen@strategie.tu-berlin.de

Magdalena Abt

magdalena.abt@web.de

1 Technische Universität Berlin, Faculty VII, H92, Straße des 17. Juni 135, 10623 Berlin, Germany 


\section{Introduction}

Since Hambrick and Mason's (1984) groundbreaking article, the study of top management teams (TMTs) has developed into a prominent area of management research (Carpenter et al. 2004). Within this area, a growing body of research now examines the presence of diverse TMT members, who are the top executive officers responsible for certain functional domains and report directly to the chief executive officer (CEO) (Hambrick and Cannella 2004; Menz 2012; Menz and Scheef 2014; Nath and Mahajan 2008; Preston et al. 2008; Strand 2013). A key premise of these studies is that the TMT structure, and the presence or absence of certain TMT positions, opens a "window into organizations" (Beckmann and Burton 2011, p. 52). Analyzing the functional roles of executive officers provides insight into organizational processes and structures (Beckmann and Burton 2011), signals which business functions are believed to be the most important, and indicates where power resides within an organization (Fligstein 1987). Additionally, the presence of certain functional TMT positions not only impacts ideologies or group processes within the upper echelon, but also drives the strategic decision-making, and, hence, affects organizational performance (Menz 2012).

Accordingly, promoting directors of human resources (HR) to the ranks of the upper echelon, and granting them titles such as chief human resources officer (CHRO) or personnel director, ${ }^{1}$ is an important structural, strategic, and symbolic choice. It signals a fundamental change in managerial roles, demonstrating the greater influence of institutionalized HR in the TMT structure. Thus, the presence of a CHRO is a reflection of the importance of HR in strategic decision-making (e.g., Brewster 1994; Budhwar 2000). Therefore, understanding how organizations handle the "human aspect" at the executive level, or the highest levels of management, allows us to investigate the upper echelons and the institutional development of capitalism as a whole. While the dominance of the chief financial officer (CFO) function indicates how capital market-driven ideologies impact how chief officers consider governance issues (Davis 2009a, b; Dobbin and Zorn 2005; Dore 2008; Zorn 2004), it remains unknown whether a human resource management (HRM)centered stream of ideology can impact this level of management as well. We live in an increasingly technology-driven knowledge society (Kasworm 2011) in which people are considered to be a firm's most important asset. HR topics, such as inventing new ways of working, building a high-performance culture, developing leaders, or recruiting talent, are at the top of most strategic agendas (Boselie and Paauwe 2005; Josephson and Reinken 2008). Some researchers and practitioners already view CHROs as crucial for the future (Wright et al. 2011), and argue that it is only a matter of time until CHROs will have equal or even more weight than CFOs (Charan et al. 2015; Donkin 1999; Groysberg et al. 2011, pp. 67-68; Welch and Welch 2005) or become favored for CEO succession (Josephson and Reinken 2008). However, many organizations, especially in the US, seem surprisingly

\footnotetext{
1 For reasons of simplicity, in this paper we use the term "CHRO" for human resource-related positions at the executive level. See the methodology section below for further information.
} 
reluctant to establish a CHRO (Aijala et al. 2007), whereas roughly $90 \%$ have established a CFO (Zorn 2004).

This study aims to understand why firms differ in having a CHRO. By providing academics and practitioners with an understanding of antecedents, this study adds to the existing body of knowledge on strategic HRM (SHRM) (see, e.g., Mello 2015), particularly as the decision to have an HR officer be a part of a TMT is one of, if not the, most important steps in the SHRM process (Welbourne and Cyr 1999). By exploring the reasons for $\mathrm{CHRO}$ presence, we also intend to contribute to strategic management and upper echelon research by answering the key research questions of how contextual conditions, organizations, and CEOs affect TMT structures and which theories and research methods are suitable for studying this issue (Carpenter et al. 2004). Our research shows that the contingency theory, which has been the dominant theoretical approach for identifying the antecedents of chief officers' presence in existing research (e.g., Hambrick and Cannella 2004; Menz and Scheef 2014; Nath and Mahajan 2008), should be supplemented by other approaches, such as homophily and the institutional theory. With regard to recent practitioneroriented recommendations highlighting the evolving role of the CHRO (Challah 2006; Charan et al. 2015), our study helps to explain the reality behind CHRO choices. Finally, by discussing the role of the CHRO in the upper echelons of a business, our paper also adds an important facet to the recent discussion on the financialization of the modern economy and the development of capitalism (e.g., Davis 2009a, b).

\section{Context, theory, and hypotheses}

The analysis of TMTs and their antecedents is dependent on the institutional and cultural context. For example, Crossland and Hambrick (2011) show empirically that nation-level institutions determine the degree of managerial discretion that CEOs have in public companies, and, more specific to our research questions, Kabst and Giardini (2009) provide data on the presence of CHROs in 27 countries, which spans from $91 \%$ in France to $25 \%$ in Turkey, with $41 \%$ in the US and $56 \%$ in Germany (data for 2005). We focus in our empirical study on US firms due to the leading role these firms have always played for the development of modern capitalism (e.g., Chandler 1990; Van Elteren 2006, ch. 9), and also because the "natural fit" between America's individualistic culture and the human-centric perspective that defines our research interest (Hofstede 1980). We therefore briefly describe this context through a historical perspective before analyzing the roles that CHROs may have. We then introduce our theoretical lenses and develop our hypotheses.

\subsection{The head of HR in US firms}

In the US, the head of the HRM function was traditionally considered "a low man" (Jacoby et al. 2005) in the managerial hierarchy. At various times, however, HR managers became more valued. In the 1940s and 1950s, most large US companies 
had personnel departments responsible for administrative tasks, such as payroll processing or record keeping, as well as for setting the company-wide employment policy, qualifying employees, and handling increasingly powerful labor unions (Bottger and Vanderbroeck 2008; Eilbirt 1959; Kaufman 2008; Kochan and Barocci 1985). Due to the increasing importance of financial criteria for intra-organizational resources and power allocation during the 1960s (Fligstein 1987) and HR professionals' inability to quantify their contributions in financial terms, HR managers were increasingly considered to be "not business oriented" (Ritzer and Trice 1969, p. 66). In the late 1960s and 1970s, the rise of unions (Beaumont and Leopold 1985), the spread of the behavioral sciences applied to personnel management in academic research, and the passage of diverse government employment laws helped again legitimize the power of HR managers in the US (Dobbin and Sutton 1998). In 1971, AT\&T perceived the strategic importance of HR and became the first firm in the US to create the position of an executive officer mainly responsible for managing HR (Bottger and Vanderbroeck 2008). In the 1980s, all of the factors that had previously bolstered the worth of HR executives in the US diminished: governmental influence shrank, unions became weaker, the unemployment rate rose, and corporate governance began focusing even more intensely on shareholder value (Jacoby et al. 2005). As HR departments weakened, the HR executives at the tops of organizations found themselves a primary target for outsourcing (Greer et al. 1999).

During recent decades, however, HR issues, such as structuring organizations to attract, develop, and retain the best workforce, inventing new ways of working that allow employees to be productive whenever and wherever they are, and creating a corporate culture that enforces moral principles and guides organizational change, have become part of the most important strategic tasks TMTs fulfill (Challah 2006; Groysberg et al. 2011). Analogously, the calls to promote the head of HR to the highest management ranks and make them a close partner to the CEO (Bottger and Vanderbroeck 2008) have recurred and strengthened. Currently, many researchers and practitioners view top HR professionals as the upcoming strategic key players (Wright et al. 2011) with a weight comparable to the CFO (Charan et al. 2015; Donkin 1999; Josephson and Reinken, 2008; Welch 2005).

\subsection{Roles of CHROs in TMTs}

Different roles for HR professionals have since emerged (Lengnick-Hall and Lengnick-Hall 2002; Storey 1992; Ulrich and Brockband 2005), which can also be applied to CHROs. Although the conceptual approaches differ in the denomination of the HR roles, they all share that HR professionals must handle operational as well as strategic duties and responsibilities and, thus, act as both a "strategist and steward" (Caldwell 2003; Kelly and Gennard 2001).

More specifically, the roles and responsibilities of CHROs can be described in four major categories (Deloitte Consulting 2006). As workforce strategists, CHROs play a key role in steering the direction of a business strategy that coincides with the current labor trends and available workforce. This is becoming more important, as "business strategy is increasingly a function of the workforce itself" (Deloitte 
Consulting 2006, p. 7). As organizational performance conductors, CHROs help implement the organizational structures that promote innovation and collaboration as well as flexible work practices that produce inspiring work. As HR service delivery owners, CHROs deliver the goods of day-to-day HR administration. Finally, as compliance and governance regulators, CHROs ensure that all activities adhere to local, national, and international laws and regulations in a business world that is affected by globalization and offshoring, and provide board development and executive succession planning.

As these categories have never been verified empirically, we compared them to 24 press releases accompanying $\mathrm{CHRO}$ appointments, $17 \mathrm{CHRO}$ job descriptions on company web sites, and insights from 12 interviews with CHROs of private firms. ${ }^{2}$ According to our qualitative research, CHROs spend most of their time as workforce strategists. Examples of CHRO tasks belonging to this category include "creating and implementing human resource strategies to support the company's long-term strategic goals", "doing everything regarding HRM to reach superior business objectives", or "identifying strategic locations targeted for workforce growth". Tasks belonging to the function of being a governance regulator, such as reviewing candidates for TMT or board membership or creating compensation packages, were not mentioned in the press releases, job descriptions, or our interviews. Instead, most often the following tasks were included: "direct HR development and talent management activities", "support employee relations", "do staffing, recruiting and retaining", "assist organizational development and change," "developing a learning organization", "management of demographic change," "transform corporate culture", or "handle compensation planning and controlling". This plethora of tasks describes the CHRO work domain in the firm as such, not so much the specific CHRO role within the inner TMT. Based on anecdotal evidence from firms such as General Electric and Tata Communications, Charan et al. (2015) recently concretized this role through three critical activities: predicting outcomes, diagnosing problems, and prescribing people-oriented actions that add value to the business.

\subsection{Selection of theory perspectives}

To study our research question in a more systematic way, we integrate different theoretical perspectives to derive the theoretically-driven antecedents of CHRO presence.

\footnotetext{
${ }^{2}$ We interviewed 12 CHROs from private firms in various industries, including air transportation, textile mill products, transportation equipment, chemicals and allied products, and communications. The company sales ranged from $\$ 593$ million to $\$ 2.95$ billion. The CHROs were all contacted by email or letter and interviewed in person or on the phone. The partly standardized interviews lasted about an hour and mainly covered the tasks and responsibilities of CHROs, the reasons for their appointment, the skill requirements, and their influence on strategic decision making. The interviews being conducted with German CHROs while our empirical study is based on a sample from the US is certainly not ideal but also not detrimental since this evidence was only used for illustrative purposes in our hypothesis development and not for hypothesis testing (for an elaboration of the idea of such a "mixed-method" approach, see, e.g., Hesse-Biber and Johnson 2015). The press releases and job descriptions refer to US companies.
} 
Previous research has revealed that contingency considerations are useful to research the antecedents of chief officers' presence, although they explain only a small proportion of variance (Hambrick and Cannella 2004; Menz and Scheef 2014; Nath and Mahajan 2008). According to Schoonhoven (1981), the contingency approach is not a distinct theory, but rather a strategy for developing hypotheses. However, Boyd et al. (2012) argue that, particularly in strategic management literature, there is an ongoing trend of referring to contingency as a theory. Therefore, we apply contingency logic and complement it with institutional and homophily viewpoints. Consequently, we argue that CHRO presence is affected by: (1) rational considerations about the costs and benefits of the position depending on situational factors (contingency theory), (2) less-economical processes of legitimization and institutionalization at the industrial and organizational levels (institutional theory), and (3) individual experiences and preferences of TMT members (homophily theory). Thereby, we respond to Okhuysen and Bonardi's (2011) call for more "multiple-lens explanations" in management research. Further, Maritan and Peteraf (2008, p. 71) indicate that combining multiple theories and perspectives from research fields such as "economics, sociology, behavioral science and social science" (...) "can generate richer insights" for strategic management research. By using different theories, we analyze the reasons for CHRO presence at the micro (TMT members), meso (organization), and meta (industry) levels. Consequently, we consider these explanations as complementary and investigate what these explanations can contribute to our understanding of $\mathrm{CHRO}$ presence in TMTs.

\subsection{CHROs on TMTs: a contingency perspective}

According to the contingency theory, there is no single best way to structure an organization. Instead, the suitability of organizational structures and characteristics depends on internal and external contingencies (Donaldson 2001). Only after considering the costs and benefits of different possibilities, while also allowing for internal and external contingencies, can the most efficient alternative be chosen. In this way, organizational structure and characteristics are shaped by situational factors (e.g., Child 1975; Schreyögg 1980).

We apply this logic to researching the reasons for CHRO presence in TMTs. In line with previous research that applies the contingency perspective (Hambrick and Cannella 2004; Menz and Scheef 2014; Nath and Mahajan 2008; Zorn 2004), we base our analysis on the assumption that CHRO presence is more useful, and therefore more likely, when HR issues cause complexity and uncertainty at the apex of a firm. By analyzing prior empirical and theoretical publications, especially from within research streams on TMTs (Finkelstein et al. 2009; Menz 2012) and SHRM (Caldwell 2003; Welbourne and Andrews 1996), and condensing the indicative evidence extracted from our qualitative research, we focus on five regularlyoccurring factors that increase HR complexity at the top of an organization, and thus drive the appointment of a CHRO. These are the representation of unions, the knowledge-intensity of a firm, major strategic or organizational changes indicated by changes in the number of employees, and employment of a new or outsider CEO. 


\subsubsection{Representation of unions}

Collective bargaining negotiations between labor unions and corporate employers include sensitive topics such as pension plans, health benefits, working conditions, pay rates, hours worked per week, and number of paid days of leave, and are partly governed and mandated by external laws. As the goals of the negotiating parties are often incompatible, conflicts between management and unions are likely. Negotiations with unions are thus considered to be important and sensitive. The higher the rate of unionization within an enterprise, and the more power unions gain, the more complex bargaining negotiations become, especially when there is a variety of unions (Craver 1997; Jackson and Schuler 1999). As our interviews indicated, conducting these negotiations is a task fulfilled by CHROs. One CHRO described, "I have a very close relationship with labor union representatives; we fight nearly every day." Admittedly, the union membership rate has recently decreased globally and especially in the US. In 2015, union membership decreased to only 11.1 percent (and 6.6 percent in the private sectors) from 20.1 percent in 1983, according to data from the US Bureau of Labor Statistics (http://www.bls.gov/news.release/union2. nr0.htm; retrieved on May 2, 2016). However, unions can put pressure on employers by forming coalitions with other interest groups (e.g., environmental activists) (Tattersall 2010). Furthermore, Huselid (1995) and Pfeffer (1998) state that the existence of and positive relations with unions suit other high performance work practices. They also suggest, at least implicitly, that $\mathrm{CHRO}$ representation could signal an appreciation of the importance that unions have for the workplace climate and, eventually, for firm performance. Thus, we propose the following hypothesis:

Hypothesis 1 A firm's rate of unionization is positively related to the likelihood of CHRO presence on its TMT.

\subsubsection{Strategic and organizational change}

HRM is of special importance during episodes of strategic or organizational change (Galpin 1996). New strategic directions may require competencies that have to be developed, and restructuring activities usually provoke resistance to change that must be overcome (Kotter 1995). We focus on episodes of growth and downsizing, which have received considerable attention in existing literature (see, e.g., Datta et al. 2010; Phelps et al. 2007). When a company's body of employees increases or decreases rapidly (in terms of the number of employees), a high percentage of employees must be hired, displaced, trained, or laid off. Further, reward systems and career ladders (e.g., those for middle managers) must be revised and HR development activities or recruitment strategies adapted (Finegold and Frenkel 2006). One of our interviewees formulated it as follows: "Finding the right people is the basis for any growth strategy and thus determines our growth targets-before we decide about market penetration, market expansion, or diversification strategies, I have to evaluate how to provide the required employees." Another CHRO stated, "Of course I play a key role in every decision that changes our employees' situation; if we decide to reduce our workforce, I am responsible for finding adequate 
measures and carrying on negotiations with employee representatives." These are strategic HR tasks that must be aligned to each other and to corporate strategy and, therefore, must be addressed at the very top of the firm (Brewster 1994). Previous research has concluded that when a firm's number of employees changes rapidly, integrating HR strategy and corporate strategy is even more necessary (Bennett et al. 1998) and has a greater effect on performance (Welbourne and Andrews 1996). Furthermore, HR departments are required to act as agents of change, help individual employees and departments deal with change, and shape cultures that improve organizations' capacity for change (Caldwell 2003). To meet these challenges, the integration of senior HR specialists within TMTs is essential (Brewster 1994).

Given these considerations, we formulate the following hypothesis:

Hypothesis 2 A firm's amount of change in employees is positively related to the likelihood of CHRO presence on its TMT.

\subsubsection{Knowledge intensity}

In knowledge-driven companies, intellectual and social resources are the key drivers of success, rather than financial and physical capital (Finegold and Frenkel 2006). When success depends primarily on knowledge creation, knowledge sharing, and learning, it is crucial that innovative individuals are attracted, motivated, developed, and retained by firms in accordance with their strategies (Hall and Mairesse 2006). This was confirmed in an interview with the CHRO of a pharmaceutical company. He additionally explained that HR issues are not only more important, but also more challenging. Since knowledge-oriented workers more heavily prioritize interesting and challenging work environments, appropriate work-life-balance, and competence-based pay, managing them requires more sophisticated motivational and performance management measures. Further, it demands a categorized workforce structure that is managed differently depending on whether employees fulfill operational or innovative tasks (Finegold and Frenkel 2006). Managing successful knowledge-management systems requires the strong commitment of employees, which in turn is dependent on well-elaborated HRM concepts and frameworks (Hislop 2003). As Kostova et al. (2004) stated, "The importance of the human element in building effective knowledge-management systems cannot be overstated" (p. 284). A CHRO can support the handling of all of the implications of knowledge intensity. Thus, we propose the following hypothesis:

Hypothesis 3 A firm's level of knowledge intensity is positively related to the likelihood of CHRO presence on its TMT.

\subsubsection{Outsider CEO}

The CEO is the pivotal member of the TMT, and thus has a disproportionate impact on team characteristics (Finkelstein 1992), including decisions about whether to employ a CHRO. In theory, directors of US public corporations are voted upon by the shareholders and nominated by the board as a whole or by a committee that 
should, according to the NYSE/NASDAQ listing requirements in the SarbanesOxley Act of 2002, consist of independent directors. However, there is much empirical evidence suggesting that, in practice, the inside directors and especially the CEO still have a decisive impact on the selection process (Cai et al. 2009; Coles et al. 2014; Hermalin and Weisbach 2003; Shivdasani and Yermack 1999), although there may be considerable variance between companies (Clune et al. 2014). This is in line with the observation that in many US companies, the CEO also serves as the chairman of the board (see Adams et al. 2010), and that the CEO effect on the performance of US corporations has increased (Quigley and Hambrick 2015). The implication of this is that, in addition to organizational task demands, the personal demands of the CEO affect decisions regarding the TMT composition or, more specifically, director selection. To accomplish their multiple and complex duties successfully, CEOs compensate for their own possible limitations through the staffing of their executive teams. One issue relevant to CEOs' staffing decisions is their familiarity with their firms. CEOs who have risen through the ranks internally are familiar with the technologies, markets, people, processes, and cultures of their firms (Beckmann and Burton 2011). Outsider CEOs lack such knowledge, and therefore require assistance from internal experts. Based on this logic, Hambrick and Cannella (2004) demonstrated that outsider CEOs are more likely to have chief operating officers (COOs), while Nath and Mahajan (2008) discovered that the probability of chief marketing officer (CMO) presence increases with an outsider CEO. We argue that this interrelationship also applies to $\mathrm{CHRO}$ presence, with the one caveat that human capital may have general, firm- and industry-specific components (Becker 1975; Neal 1995) and that only the latter two apply in our context. We assume that to develop or sustain the firm's competitive advantage, unique technological and market-related human skills and competencies (as cited above, "as business strategy is increasingly a function of the workforce itself;" Deloitte Consulting 2006, p. 7) are necessary. Thus, we hypothesize the following:

Hypothesis 4 The likelihood of CHRO presence on a TMT is higher in firms with an outsider CEO than in firms with an insider CEO.

\subsubsection{New CEO}

Not only short tenure within an organization but also short tenure in the CEO position limits the knowledge and capabilities of CEOs. According to Hambrick and Fukutomi (1991), new CEOs lack knowledge of the facts, contracts, trends, or procedures that pertain to being a successful CEO. To overcome this limitation, they gather information from various sources, and prefer to have diverse advisors from different functional domains (McDonald and Westphal 2003). During their tenures, CEOs largely overcome related handicaps by acquiring critical task knowledge. They also learn about the qualities and capabilities of their advisors, which enables them to rely only on qualified advice, rather than on varying unfiltered advice. As such, they tend to reduce senior staffing levels (Hambrick and Fukutomi 1991). Therefore, we propose the following hypothesis: 
Hypothesis 5 The likelihood of CHRO presence on a TMT is higher in firms with a new CEO than in firms with a CEO who has a long tenure.

\subsection{CHROs on TMTs: an institutionalization mechanism}

According to the contingency theory, organizational decisions are based on rational considerations about the costs and benefits of different possibilities. However, the most efficient alternative is not always selected. Our interviewees confirmed that they experience explanations such as, "We have always done it this way" or "Our competitors do it that way" on a near daily basis. The sociological approach of the institutional theory explains this reasoning by arguing that individuals and organizations seek approval and legitimacy for their behavior, structures, and processes in socially constructed environments by adapting their business practices, processes, programs, and structures to social norms (including "Zeitgeist" and fashions that are "in the air," see e.g. Abrahamson 1991) and internal or external forces (DiMaggio and Powell 1983; Meyer and Rowan 1977). Internal forces include formalized structures and processes or informal groups. External forces include state-enacted laws and regulations, professional association licenses and certifications, and the influence of other organizations that may serve as thought leaders or trendsetters. Paawe and Boselie (2003), among others, suggest that institutional forces and social pressure can also explain the occurrence of strategic HRM policies and practices in organizations, and formulated a number of propositions that describe the effect of mimetic, normative, and coercive mechanisms.

In line with these assumptions, Jackson and Schuler (1999, p. 6) formulated two assertions of the institutional theory: (1) "institutionalized activities are resistant to change" and (2) "organizations in institutionalized environments are pressured to become similar." The first assertion indicates that structures and processes within an organization, like the presence or absence of a CHRO, are based on the historical roots of the organization and cannot be changed easily (Hambrick et al. 1993). Organizations tend to demonstrate "path dependencies" (Sydow et al. 2009) and "structural inertia" (Hannan and Freeman (1977; 1984). Considering this, we formulate the following hypothesis:

Hypothesis 6 The likelihood of CHRO presence on a TMT is higher if the position has been institutionalized in the firm.

The second assertion suggests that, especially in the face of uncertainty, managers may conclude that the least risky action is to imitate other organizations. This starts a process of mimetic isomorphism, and can lead to assimilation, particularly within a single industry. Summarizing research about the institutionalization processes of HR structures, practices, and policies, Björkman and Gooderham (2012) concluded that especially successful firms within the same industry are duplicated. TMT researchers showed that TMT structure and composition are objects of isomorphism and assimilation processes, especially within industries (Finkelstein et al. 2009, p. 21; Tuttle and Dillard 2007). Applying this to the presence of a $\mathrm{CHRO}$, we formulate the following hypothesis: 
Hypothesis 7 The likelihood of CHRO presence on a TMT is higher if the position has been institutionalized within the industry.

\subsection{CHROs as a homophilic phenomenon}

Conversely, the homophily theory (Lazarsfeld and Merton 1954; McPherson et al. 2001; Montoya and Horton 2013) suggests that the decision to employ a CHRO is not determined by rational considerations nor by issues of legitimacy, but instead is based on the personal interests and biases of the TMT. Simply, having a CHRO is based on how and with whom the TMT members want to work with and on which topics. This theory asserts that most human interaction occurs between a source and a receiver who are homophilous, meaning they are similar or congruent. Interaction with similar people is considered to be more enjoyable (Tsui et al. 1992) and more effective, as homophily produces credibility, reliability, and trustworthiness (McCroskey et al. 1974).

This tendency is especially noticeable in groups that influence their own compositions, shoulder great responsibility, and require much time, such as TMTs (Hwang and Kim 2009). The functional domain has been shown to discriminate fairly well between people in this regard (Hambrick and Mason 1984) and has proven to be an important homophily criterion. For instance, Nath and Mahajan (2008) detailed that CMOs are more likely to be present when TMT marketing experience is high. Furthermore, Marsden (1987) found that most personal networks are highly homophilous regarding members' levels of education and occupations (including in functional domains), while Verbrugge (1983) concluded that education and occupation are involved at roughly the same level in homophily as religion and gender. These results indicate that function is a significant homophily criterion, and suggest that HR professionals trust, understand, or feel attracted to people with similar HR experience.

Given the high impact of CEOs on director selection decisions, homophily considerations should also be considered. As Zhu and Westphal (2014: 793) write, "a CEO with a functional background in marketing may tend to focus on issues related to marketing in assessing strategic problems and opportunities, and if a new director does not appreciate the CEO's marketing oriented approach to diagnosing strategic issues, the CEO will face a greater risk of conflicts and power struggles with the new director in subsequent years (...). Research on board appointments also suggests that avoiding such uncertainty often becomes a major concern of CEOs in new director appointment decisions. "3 Thus, consistent with the idea of homophily, CEOs with HR experience are more likely to recognize the importance of people-related issues and thus be more willing to introduce or maintain CHROs. As Kelly and Gennard (2002: 2) concluded, "Chief Executives are key players in the appointment of a director. The research shows it is unlikely an HR professional will reach board or executive group level unless the organization's chief executive

\footnotetext{
${ }^{3}$ Zhu and Westphal (2014) show that even in times when powerful shareholders may influence CEOs to search for board member candidates with diverse backgrounds and weak ties to the CEO's own social circles, there is a tendency for the CEO to search for candidates who have successfully worked with other CEOs who are similar to the focal CEO.
} 


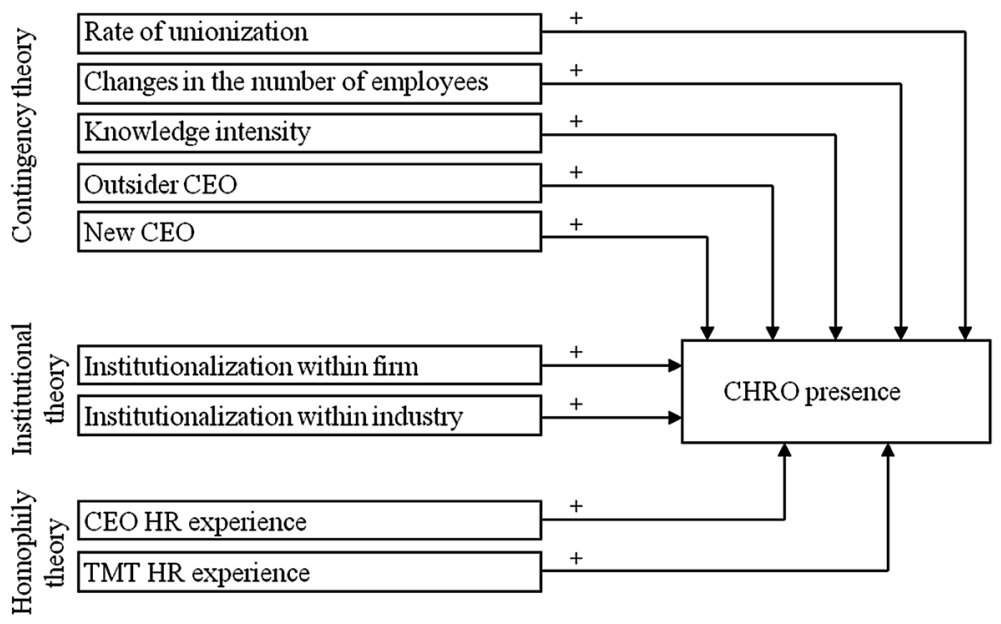

Fig. 1 Model of factors associated with CHRO presence

has a positive attitude to HR." On the basis of this discussion, we propose the following hypothesis:

Hypothesis 8 CEO HR experience is positively related to the likelihood of CHRO presence on a TMT.

Responsibility for staffing the TMT and deciding its functional composition generally lies with the CEO. Nevertheless, the CEO's ability to make such decisions without constraints depends to some extent on other stakeholders, such as other top executives (Finkelstein et al. 2009, p. 150). Hambrick and Mason (1984) also stressed that it is not always the CEO who makes important decisions, and that "although it is true that in most firms the chief executive officer has the most power, it still is of interest to study management teams" (p. 196). Hence, we also apply the homophily theory and hypothesize the following:

Hypothesis 9 TMT HR experience is positively related to the likelihood of CHRO presence on a TMT.

The following Figure summarizes our hypotheses, grouping them according to the contingency, institutional, and homophily theories (Fig. 1).

\section{Research methodology}

We studied our hypotheses by examining a sample of US Fortune 500 companies. The US represents the most advanced status of modern capitalism and also has a leading part in establishing the role of a strategically oriented CHRO position (Challah 2006). Given the tendency of low CHRO prevalence, even among Fortune 500 enterprises, we found it necessary to limit our study to firms with at least $\$ 250$ million in sales. Similar cutoffs have been made in other studies about the 
composition of TMTs (Hambrick and Cannella 2004; Marcel 2009; Nath and Mahajan 2008). We chose to observe firms over a significant period of time rather than at a single point so our results do not reflect the specific conditions or reporting idiosyncrasies of a particular year. Furthermore, we used longitudinal data to control for prior states and reverse causality. At the time the study was initiated, the most recent year secondary data was available was 2007. Thus, we chose to relate our study to the years 1998 through 2007, which also offers an advantage in that our results are not distorted by the financial crisis of 2008. The sample was selected by identifying all public corporations reporting at least $\$ 250$ million in sales in the year 2003, which was the midpoint of our observation period, through the Compustat database published by Standard \& Poor (S\&P). From this set, all firms without missing data on the antecedent factors in the Compustat database were included. We then used the $10-\mathrm{K}$ and $8-\mathrm{K}$ reports submitted to the Securities and Exchange Commission (SEC) for lists of officers, titles, and further antecedent factors, and collected annual data for all companies from 1998 through 2007 for the dependent variable, and 1995 (due to a three-year lag for institutionalization) through 2006 for the independent variables. This data was available for a total of 241 firms. We identified the primary two-digit code for every company and, to control for industry effects, retained only industries with more than 10 such firms. Finally, we arrived at an overall sample of 215 firms, or 2150 firm-years, across 12 industries. The excluded firms did not systematically differ from the firms retained in the sample.

\subsection{Operationalization of the TMT members and CHRO presence}

TMTs have been operationalized in various ways, as shown in prior studies (for an overview of different operationalization approaches, see Table 1 in Carpenter et al. 2004). We use the most inclusive operationalization that offers consistency with recent comparable studies (e.g., Menz and Scheef 2014; Nath and Mahajan 2008). More specifically, in this study, TMTs include all executive officers listed in the 10-K filings or proxy statements (e.g., 10-Q or 8-K). For 2007, which was the only year for which we considered TMT size, since this was solely measured to control for operationalization and was not included in any statistical analyses, the mean size of TMTs in the sample was 9.56 individuals, with a standard deviation of 3.20, which is consistent with prior research using such broad operationalization. The variable "CHRO presence" was coded as 1 (for the presence of a CHRO) when executives with the words "human," "personnel," or "people" in their titles were listed in TMTs, and was coded 0 (for the absence of a CHRO) otherwise.

\subsection{Antecedents}

To address reverse causality, we collected all antecedent variables by using a oneyear lag $(t-1)$ and updated them for each year from 1997 through 2006 (cf. Hambrick 2007, p. 338). Most of our measures and all of our data sources have been used previously. 


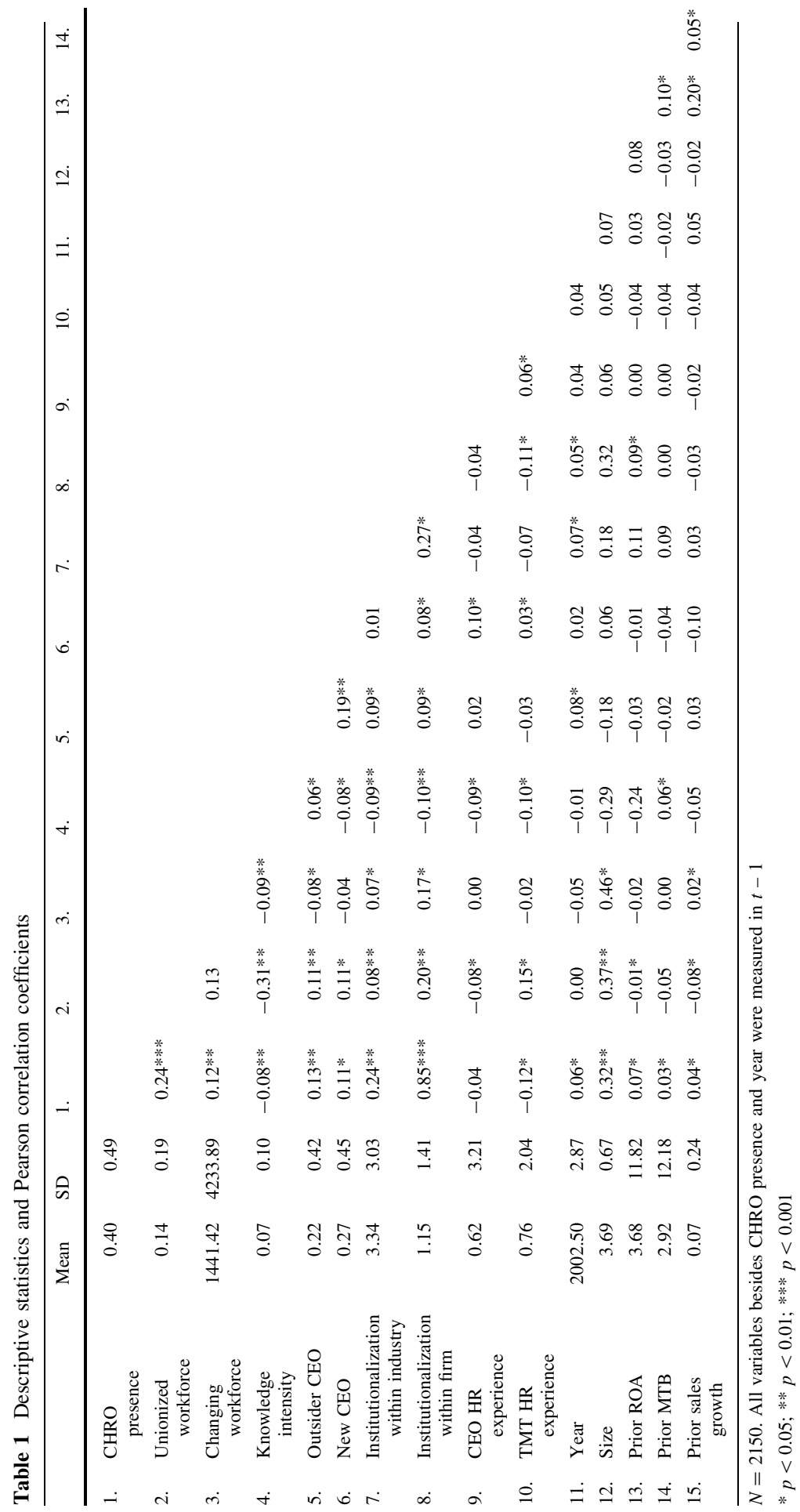




\subsubsection{Antecedents belonging to contingency theory}

To detect the rate of unionization, we collected data on the percentage of employees organized in unions from the 10 -K filings (the same operationalization is used by the Bureau of Labor Statistics; Blanchflower 2007; Faber 2005). Radical workforce changes were captured by the difference between the minuend number of employees in $t-2$ and the subtrahend number of employees in $t-1$ (1-year time lag included) (Kivimäki et al. 2001). The knowledge intensity of a firm was captured by the ratio of research and development $(R \& D)$ costs to sales or $R \& D$ intensity. This measure was introduced by the OECD in the mid-1980s, and has since then been widely used as an indicator of knowledge intensity (see OECD 2001, and as examples, Coff 2003; Leydesdorff et al. 2006). These data were collected from S\&P's Compustat. The values for the antecedents "Outsider" and "New CEO" were collected from the 10-K filings. "Outsider CEO" was captured as a binary variable, with a value of 1 if the $\mathrm{CEO}$ had joined the firm no more than 2 years prior to becoming a CEO, and 0 otherwise (cf. Cannella and Lubatkin, 1993; Hambrick and Cannella 2004; Zhang 2006). "New CEO" was captured as a binary variable with a value of 1 if the CEO was in their first 3 years in the position, and 0 otherwise (cf. Hambrick and Cannella 2004).

\subsubsection{Antecedents belonging to institutional theory}

In line with Hambrick and Cannella (2004), we regarded institutionalization within an industry as being operationalized by the presence or absence of a CHRO position within the three biggest or, alternatively, the three most profitable firms in the industry for the last 3 years. The biggest firms were defined by their respective sums of employees for the years $t-3, t-2$, and $t-1$. The most profitable firm was defined by its return on assets for the years $t-3, t-2$, and $t-1$. The three biggest or three most profitable firms in each industry were updated for each year. We collected all size and performance measures from S\&P's Compustat. Subsequently, we constructed a variable that counted the number of years among $t-3, t-2$, and $t-1$ in which one or more of the three organizations had a CHRO. The variable ranged from 0 to 9 , and was calculated for all industries. Institutionalization within an organization was operationalized by the presence or absence of the CHRO position in the organization for 3 years, with a 3-year time lag. For this purpose, we constructed a variable that counted the number of years among $t-5, t-4$, and $t-3$ in which the organization had a CHRO. As is logical, the variable ranged from 0 to 3 .

\subsubsection{Antecedents belonging to homophily theory}

According to the homophily theory, TMT members choose to establish a CHRO position when they are highly experienced in HRM. To test this hypothesis, we operationalized the TMTs' HR experience. We measured TMT HR experience by the accumulated years that the top executive team members, excluding the CHRO, had performing HR functions. This method of classification of functional experience 
is well-established in existing research (see Finkelstein et al. 2009, pp. 97-106, for a review). We collected biographical data on TMT members by using 10-K filings, and checked the filings against other annual company reports and corporate websites. Biographical data was available for $98 \%$ of the executives. When there were no data available for a TMT member, the member was removed from the analysis. As the CEO is the most powerful person within a TMT, we collected separate data for the CEOs.

\subsection{Controls}

We controlled for a broad array of variables that may affect CHRO presence but are beyond the scope of this study. We included the year variable (ranging from 1998 to 2007) to control for time trends (Hambrick and Cannella, 2004). We controlled for firm size, as measured by the logarithm of the number of employees. We also included prior performance $(t-1)$ to control for CHRO appointments that were due to good (or bad) performance. Prior performance was measured by the return on assets (ROA), market-to-book value (MTB), and prior sales growth. Data were collected from S\&P's Compustat.

\subsection{Analysis and results}

Table 1 presents the descriptive statistics and correlations for the dependent variable, the antecedents, and the control variables. All correlations are under 0.50 and none of the variation inflation factors (VIF) are above 3.1, which implies the absence of multicollinearity problems (Mansfield and Helms 1982, p. 158). ${ }^{4}$

The mean of CHRO presence is 0.40 , meaning that CHROs were present on TMTs in $40 \%$ (860) of the 2150 firm years. The percentages of the annual occurrence of CHROs were, chronologically, 37.2, 37.3, 36.8, 35.9, 38.0, 41.0, 43.7, 43.3, 43.3, and $43.5 \%$ for the years 1998-2007.

\subsection{Reasons for CHRO presence}

In line with other studies on the antecedents of a functional position on TMTs (e.g., Hambrick and Cannella 2004), this analysis assumes that decisions about whether to have a CHRO are at least implicitly revisited on an annual basis. Hence, the analysis is based on data covering 2150 firm years. To analyze the reasons for CHRO presence, we modeled it over 1998-2007 as a function of the hypothesized antecedents and controls. All antecedents and controls were updated each year, and lagged values (for $t-1$, except where noted) were used, which enabled us to rule out reverse causality. Given that our dependent variable, CHRO presence, is binary, and that we repeatedly observed the same organizations over a 10-year period, we used the generalized estimating equations (GEE) approach of Zeger and Liang (1986a, b) to handle autocorrelations. The GEE approach weights the data with estimates of serial correlations, which occur normally in repeated data, before

\footnotetext{
${ }^{4}$ All statistics were calculated with the statistics software SPSS (version16).
} 
estimating the regression coefficients and standard errors. The GEE approach has been used to model binary outcomes with repeated data in prior studies (Hambrick and Cannella 2004; Menz and Scheef 2014; Nath and Mahajan 2008).

As Table 2 shows, the control variables of year, size, and prior sales growth have significant positive influences on CHRO presence in some models. Furthermore, a high representation of unions and high levels of change in the number of employees have positive impacts on the $\mathrm{CHRO}$ presence in model 2, although with low significance. This partially supports hypotheses 1 and 2 . Regarding the impact of unionization, we also collected data on the number of unions that organizations had to work with, as well as the number of problems that organizations had with unions in the preceding year, such as strikes, work stoppages, and intensive negotiations. The results do not differ significantly for the alternative measures. We found that knowledge intensity does not significantly influence CHRO presence. Therefore, hypothesis 3 is not supported. However, we also determined that the presence of a CHRO is more likely if a CEO is an outsider or new to the position. These results provide evidence in support of hypotheses 4 and 5. If the CHRO position is institutionalized within an organization or industry, the presence of a CHRO is also more probable, which supports hypotheses 6 and 7 (models 3 and 5), although with low significance. We found that the CEO's HR experience, on the other hand, has no impact on CHRO presence, while the TMT's HR experience has a negative impact on CHRO presence in model 4. Thus, no evidence for hypotheses 8 and 9 was found.

Among the different theories on CHRO presence (models 2-4), the institutionalization theory explains the most variance, as the variables of this theory result in the lowest QICC value. ${ }^{5}$ When all variables are put in one model (model 5), the contingency factors "unionization" and "change in the number of employees" and the variable "TMT HR experience" lose their significant effect on CHRO presence, the contingency variables "Outsider CEO" and "New CEO" and the variable "institutionalization within the industry" decrease in significance, and the variable "institutionalization within the firm" remains highly significant $(p<0.001)$.

Although we attempted to identify the most relevant contingencies in advance, the low variance explained by the contingency factors could be due to the lack of application of all relevant contingencies. To gain deeper insight, we also calculated our models with additional contingencies, such as labor intensity (assets/employees), average pay (salaries and benefits/employees), productivity (sales/employees), and unstable productivity (productivity $t-2$ /productivity $t-1$ ). However, none of these contingencies decreased the QICC by more than 5.00. Another possibility may be that CHROs are only present when there are certain combinations of antecedent conditions (Huselid 1995; Pfeffer 1998). For instance, the representation of unions is more influential in big firms than in medium-sized firms. To explore such possibilities, we also examined 14 two-way interactions and combined all contingency factors with each other. Furthermore, we combined the contingencies

\footnotetext{
${ }^{5}$ QICC is the corrected version of the quasi-likelihood under the independence criterion, which penalizes for model complexity. QICC can be used to choose the best model and, therefore, the best subset of predictors. A smaller QICC value indicates a better model fit.
} 
Table 2 Reasons for CHRO presence

\begin{tabular}{|c|c|c|c|c|c|}
\hline & Model 1 & Model 2 & Model 3 & Model 4 & Model 5 \\
\hline Constant & $\begin{array}{c}37.85 \\
(45.18)\end{array}$ & $\begin{array}{c}46.48 \\
(45.73)\end{array}$ & $\begin{array}{r}-11.90 \\
(21.63)\end{array}$ & $\begin{array}{c}35.70 \\
(41.88)\end{array}$ & $\begin{array}{l}-43.08 \\
(62.107)\end{array}$ \\
\hline Year & $\begin{array}{c}1.04 * \\
(0.22)\end{array}$ & $\begin{array}{c}1.05 \\
(0.22)\end{array}$ & $\begin{array}{c}0.91 \\
(0.26)\end{array}$ & $\begin{array}{c}1.05 \\
(0.23)\end{array}$ & $\begin{array}{c}0.89 \\
(0.25)\end{array}$ \\
\hline Size & $\begin{array}{l}0.91 * * \\
(0.04)\end{array}$ & $\begin{array}{c}0.91 * \\
(0.04)\end{array}$ & $\begin{array}{c}0.59 \\
(0.05)\end{array}$ & $\begin{array}{c}0.92 * \\
(0.04)\end{array}$ & $\begin{array}{c}0.91 \\
(0.04)\end{array}$ \\
\hline Prior ROA & $\begin{array}{c}0.00 \\
(0.00)\end{array}$ & $\begin{array}{c}0.00 \\
(0.00)\end{array}$ & $\begin{array}{c}0.00 \\
(0.00)\end{array}$ & $\begin{array}{c}0.00 \\
(0.00)\end{array}$ & $\begin{array}{r}-0.01 \\
(0.00)\end{array}$ \\
\hline Prior MTB & $\begin{array}{c}0.00 \\
(0.00)\end{array}$ & $\begin{array}{c}0.00 \\
(0.00)\end{array}$ & $\begin{array}{c}0.02 \\
(0.00)\end{array}$ & $\begin{array}{c}0.00 \\
(0.00)\end{array}$ & $\begin{array}{c}0.03 \\
(0.00)\end{array}$ \\
\hline Prior sales growth & $\begin{array}{c}0.06^{*} \\
(0.02)\end{array}$ & $\begin{array}{c}0.02 * \\
(0.01)\end{array}$ & $\begin{array}{c}0.10 \\
(0.05)\end{array}$ & $\begin{array}{c}0.02 * \\
(0.01)\end{array}$ & $\begin{array}{c}0.09 \\
(0.02)\end{array}$ \\
\hline Unionized workforce & & $\begin{array}{l}3.89 * * \\
(0.82)\end{array}$ & & & $\begin{array}{c}2.53 \\
(0.95)\end{array}$ \\
\hline Changing workforce & & $\begin{array}{c}0.34 * \\
(0.07)\end{array}$ & & & $\begin{array}{c}0.42 \\
(0.14)\end{array}$ \\
\hline Knowledge intensity & & $\begin{array}{r}-1.15 \\
(1.23)\end{array}$ & & & $\begin{array}{r}-2.09 \\
(1.37)\end{array}$ \\
\hline Outsider CEO & & $\begin{array}{l}2.93 * * \\
(0.21)\end{array}$ & & & $\begin{array}{c}2.03^{*} \\
(0.20)\end{array}$ \\
\hline New CEO & & $\begin{array}{l}1.33 * * \\
(0.32)\end{array}$ & & & $\begin{array}{c}1.34 * \\
(0.35)\end{array}$ \\
\hline Institutionalization within industry & & & $\begin{array}{l}1.03 * * \\
(0.16)\end{array}$ & & $\begin{array}{c}1.04 * \\
(0.16)\end{array}$ \\
\hline Institutionalization within firm & & & $\begin{array}{l}7.72 * * * \\
(0.53)\end{array}$ & & $\begin{array}{l}6.72 * * * \\
(0.46)\end{array}$ \\
\hline CEO HR experience & & & & $\begin{array}{r}-0.07 \\
(0.04)\end{array}$ & $\begin{array}{r}-0.04 \\
(0.03)\end{array}$ \\
\hline TMT HR experience & & & & $\begin{array}{r}-0.79 * \\
(0.14)\end{array}$ & $\begin{array}{r}-0.53 \\
(0.27)\end{array}$ \\
\hline QICC & 914.17 & 895.62 & 358.00 & 908.53 & 354.60 \\
\hline
\end{tabular}

$N=2150$. Standard errors are in parentheses. All variables besides CHRO presence and year were measured in $t-1$

Model 1 includes only control variables, model 2 control and contingency variables, model 3 control and institutional variables, model 4 control and homophily variables, and model 5 control, contingency, institutional, and homophily variables. Size is measured by a firm's number of employees less the mean value at a two-digit SIC level (no logarithm is used). We used M-dependent as working correlation matrix structure and logit as link function

$* p<0.05 ; * * p<0.01 ; * * * p<0.001$

"rate of unionization" and "knowledge intensity" with the control variable "size." The likelihood of CHRO presence increases when the CEO is an outsider and simultaneously new to the position. However, apart from this combination, none of 
the other two-way interactions yielded significant results, nor did any decrease QICC by more than 5.00.

Since institutionalization in a firm was found to be a highly significant antecedent of CHRO presence, we examined the annual CHRO occurrence in single firms more closely (cf. Hambrick and Cannella 2004). We identified 102 firms (47.4\%) that always had a CHRO during the observed 10-year period, and compared them to the 57 firms $(26.5 \%)$ that did not have a CHRO at any time. We defined "CHROproneness" ( 1 if the firm had a CHRO for all 10 years) as a new dependent variable, and adjusted all antecedents and sizes by calculating the averages across the observed period. We also tested the influence of all contingency factors on "CHROproneness", "institutionalization within the industry", and homophily variables, by using logistic regressions. As our dependent variable "CHRO-proneness" and independent variable "institutionalization within firm" correlate by definition, we excluded this antecedent from our analysis. We first tested the variables from each theory separately before combining all variables in one model. The results, as shown in Table 3, support those of the earlier GEE analyses. The results for the variable "institutionalization within the industry" were particularly notable, as they not only had the most significant influence, but also explained the most variance.

To ensure that the industry effects were due to institutionalization and legitimization aspects, rather than other industry peculiarities, we also more closely considered CHRO presence by industry. Table 4 shows that, at this level of analysis, there are major differences in the percentages of CHRO presence. To determine whether the differences are caused by legitimacy aspects or context conditions, we examined whether our contingency variables varied systematically across industries and verified these results with the different industry measures published by the US Bureau of Labor Statistics. We controlled for the possibility that unemployment rates, mass layoff events, wages of employees, injury rates, training requirements, qualifications of workers, hours worked per week, or benefits offered by trade (e.g., health insurance, pension plans) influenced the incidence of CHROs. However, no underlying pattern could be found. Although it is possible that industries develop conventions or traditions that predispose them to having a CHRO, this incidence is not anchored with any observable contextual contingency.

\section{Discussion and directions for further research}

The purpose of this study was to determine the factors associated with the likelihood of a CHRO on a TMT, and establish what theories are suitable for explaining these factors.

By testing different theories and exploring approaches that motivate having a TMT member primarily responsible for HR issues, we analyzed different rationales for the composition of TMTs. In doing so, we particularly contribute to the growing, but still sparse, body of upper echelon research that analyzes the determinants of particular functional TMT roles. As the presence of a CHRO is an important factor for HR influence on corporate strategy, this study equally contributes to the dialog on the strategic role of HRM (e.g., Caldwell 2003; Hailey et al. 2005; Pfeffer 1998; 
Table 3 Results of logistic regression with CHRO-proneness as dependent variable

\begin{tabular}{|c|c|c|c|c|c|}
\hline & Model 1 & Model 2 & Model 3 & Model 4 & Model 5 \\
\hline Constant & $\begin{array}{c}-4.58 \\
(3.18)\end{array}$ & $\begin{array}{r}-5.69 \\
(3.54)\end{array}$ & $\begin{array}{r}-4.33 \\
(2.85)\end{array}$ & $\begin{array}{c}-3.18 \\
(2.33)\end{array}$ & $\begin{array}{c}-3.71 \\
(3.18)\end{array}$ \\
\hline Size & $\begin{array}{c}0.34 * \\
(0.05)\end{array}$ & $\begin{array}{c}0.32 * \\
(0.05)\end{array}$ & $\begin{array}{c}0.29 * \\
(0.04)\end{array}$ & $\begin{array}{c}0.31 * \\
(0.05)\end{array}$ & $\begin{array}{c}0.24^{*} \\
(0.05)\end{array}$ \\
\hline Prior ROA & $\begin{array}{c}0.01 \\
(0.01)\end{array}$ & $\begin{array}{c}0.08 \\
(0.01)\end{array}$ & $\begin{array}{c}0.00 \\
(0.00)\end{array}$ & $\begin{array}{c}0.05 \\
(0.01)\end{array}$ & $\begin{array}{c}0.06 \\
(0.01)\end{array}$ \\
\hline Prior MTB & $\begin{array}{r}-0.04 \\
(0.01)\end{array}$ & $\begin{array}{c}0.01 \\
(0.00)\end{array}$ & $\begin{array}{c}-0.05 \\
(0.01)\end{array}$ & $\begin{array}{c}-0.21 \\
(0.01)\end{array}$ & $\begin{array}{c}0.00 \\
(0.00)\end{array}$ \\
\hline Prior sales growth & $\begin{array}{r}-0.06 \\
(0.05)\end{array}$ & $\begin{array}{c}0.01 \\
(0.05)\end{array}$ & $\begin{array}{c}-0.03 \\
(0.04)\end{array}$ & $\begin{array}{r}-0.04 \\
(0.05)\end{array}$ & $\begin{array}{r}-0.02 \\
(0.04)\end{array}$ \\
\hline Unionized workforce & & $\begin{array}{c}0.08^{*} \\
(0.01)\end{array}$ & & & $\begin{array}{c}0.04 * \\
(0.01)\end{array}$ \\
\hline Changing workforce & & $\begin{array}{c}0.24 * \\
(0.07)\end{array}$ & & & $\begin{array}{c}0.17 * \\
(0.07)\end{array}$ \\
\hline Knowledge intensity & & $\begin{array}{r}-0.06 \\
(0.12)\end{array}$ & & & $\begin{array}{r}-0.01 \\
(0.13)\end{array}$ \\
\hline Outsider CEO & & $\begin{array}{c}0.16^{*} \\
(0.03)\end{array}$ & & & $\begin{array}{c}0.12^{*} \\
(0.03)\end{array}$ \\
\hline New CEO & & $\begin{array}{c}0.08^{*} \\
(0.01)\end{array}$ & & & $\begin{array}{c}0.04 * \\
(0.02)\end{array}$ \\
\hline Institutionalization within industry & & & $\begin{array}{l}0.22 \text { ** } \\
(0.00)\end{array}$ & & $\begin{array}{l}0.20^{* *} \\
(0.00)\end{array}$ \\
\hline CEO HR experience & & & & $\begin{array}{r}-0.15 \\
(0.16)\end{array}$ & $\begin{array}{c}0.07 \\
(0.11)\end{array}$ \\
\hline TMT HR experience & & & & $\begin{array}{r}-0.16 \\
(0.09)\end{array}$ & $\begin{array}{c}-0.26 \\
(0.10)\end{array}$ \\
\hline Nagelkerke's $R^{2}$ & 0.14 & 0.26 & 0.30 & 0.17 & 0.37 \\
\hline
\end{tabular}

$\overline{N=159 \text {. Standard errors are in parentheses. All variables besides CHRO presence were measured in }}$ $t-1$

Model 1 includes only control variables, model 2 control and contingency variables, model 3 control and institutional variables, model 4 control and homophily variables, and model 5 control, contingency, institutional, and homophily variables. Size is measured by a firm's number of employees less the mean value at a two-digit SIC level (no logarithm is used)

$* p<0.05$; ** $p<0.01 ; * * * p<0.001$

Ulrich et al. 2012) by providing rationale for the differing HR influence at the corporate level.

Our results show that the institutional theory explains most of the variance and addresses the variables that have highly significant influences on CHRO presence (Paawe and Boselie 2003). Therefore, CHRO presence mainly depends on social legitimization aspects and internal and external environment forces. This is an important finding, as most upper echelon literature analyzing the determinants of 
Table 4 Percentage of CHRO presence by industry

\begin{tabular}{lll}
\hline Industry & SIC & $\%$ \\
\hline Food and kindred products & 20 & 15.2 \\
Furniture and fixtures & 25 & 27.6 \\
Paper and allied products & 26 & 44.5 \\
Chemicals and allied products & 28 & 67.7 \\
Rubber and plastic products & 30 & 27.1 \\
Fabricated metal products & 34 & 47.6 \\
Machinery and computer equipment & 35 & 45.7 \\
Electronic and other electrical equipment & 36 & 22.1 \\
Transportation equipment & 37 & 66.0 \\
Instruments and clocks & 38 & 31.2 \\
Communications & 48 & 62.7 \\
Business services & 73 & 24.9 \\
\hline
\end{tabular}

TMT structure has concentrated on contingency factors (e.g., Hambrick and Cannella 2004; Marcel 2009; Menz and Scheef 2014; Nath and Mahajan 2008). In summary, by applying the institutional theory, our research has two important insights: (1) CHRO presence is subject to intra-organizational inertia (Hannan and Freeman 1977; 1984), and (2) CHRO presence is subject to industry-level traditions or inclinations.

The evidence for the tendency toward intra-organizational inertia contrasts with extant research that assumes or emphasizes that the composition of a TMT is at least implicitly revisited each year (Hambrick and Cannella 2004; Nath and Mahajan 2008). CHRO-proneness appears to be a characteristic that organizations either have or do not have, is deeply embedded within organizational culture, and reflects a tendency to give high strategic importance to HR-related considerations (Baron and Hannan 2002; Hannan et al. 2006).

That industry-level traditions and inclinations explain the most variance is partly in line and partly at odds with the insights and underlying paradigms of strategic management research. The classic industrial organization theories argue that industry structures determine business approaches (in our case, HRM practices) and performance, while more recent evidence shows the impact of antecedents at the business and corporate levels (for a review of this discussion, see McGahan and Porter 2002). Industry life cycle theorists (e.g., Klepper 1997) suggest that the maturity of an industry heavily influences the degree to which the industry or business/firm effects can explain variance. Similarly, the logic underlying institutional theory is that pioneers employ contingency rationales, while later adopters seek legitimacy in their organizational structures by imitating other firms (DiMaggio and Powell 1983; Meyer and Rowan 1977). Unfortunately, our sample does not allow for a systematic exploration of imitation effects in industries in a manner that corresponds to institutional theory. To facilitate inferences about precursors and followers, and therefore about imitation, future research should involve the observation of an entire industry over an extended period of time. This 
would also allow for the comparison of followers and non-adapters and, therefore, generate hypotheses regarding why some firms imitate the symbolic and strategic decision to have a $\mathrm{CHRO}$, and what role mimetic, normative and coercive pressures play in this process (following, e.g., the abovementioned propositions by Paawe and Boselie 2003). Analyzing complex institutionalization processes and historical patterns may also improve the understanding of TMT heterogeneity across industries. Finally, the inclusion of a more "agentic" view within institutional theory, as opposed to the "structuralist camp" on which we have relied so far (Heugens and Lander 2009), may assist in determining why firms may deviate from well-established norms and act as institutional entrepreneurs to create CHRO roles.

In addition to institutionalization aspects, rational considerations influence CHRO presence. According to the contingency theory, CHRO presence is more beneficial and, therefore, more likely when critical areas of the HR domain are more complex and uncertain. The results for most of our contingency variables, such as the rate of unionization, strong increase or decrease in employees, and having an outsider or new $\mathrm{CEO},{ }^{6}$ support this assumption to a certain extent. However, whether this can be qualified as rational requires testing the performance implications of $\mathrm{CHRO}$ presence, in line with existing research of chief officers (see, e.g., Hambrick and Cannella 2004; Marcel 2009; Nath and Mahajan 2008). We do indeed have weak evidence that $\mathrm{CHRO}$ presence has positive performance implications, especially when HR issues cause complexity at the apex of the firm and/or other TMT members are less experienced in HRM (Abt and zu KnyphausenAufseß 2010). However, Hambrick (2007) argues that the measurement of performance implications makes more sense on the team level than on the level of individual team members (such as the CHRO). Simultaneously, we believe a careful evaluation of performance implications must go beyond focusing on financial success and should, for example, consider the possibility that the CHRO establishment primarily serves symbolic management functions (see e.g., Galang and Ferris 1997). Thus, we suggest a more careful theoretical and empirical conceptualization of firm performance from what has been employed in existing studies (Miller et al. 2013). We also believe that a better understanding of the daily function of a CHRO and how it is embedded into the overall SHRM system is required. To gain such an understanding, the application of a strategy-as-practice perspective could be helpful (for an overview see Jarzabkowski and Spee 2009, and for an application in TMT research Angwin et al. 2009). The inclusion of these additional theoretical perspectives as well as empirical approaches are beyond the scope of our paper, but present opportunities for further research.

The formulated homophily hypotheses could not be confirmed by our results. In opposition to the principles of the homophily theory, some researchers argue that diversity exists among members of task-oriented teams, especially with respect to achieved characteristics, such as functional backgrounds (Ruef et al. 2003; for metastudies on the diversity perspective, see Homberg and Bui 2013 and Horwitz and Horwitz 2007). In our study, TMT or CEO HR experience had neither a significant

\footnotetext{
${ }^{6}$ Our results regarding the impact of knowledge intensity on CHRO presence will be briefly discussed below.
} 
positive nor negative influence on CHRO presence. Thus, neither the homophily theory nor diversity approaches were empirically supported. Nevertheless, we believe that homophily aspects influence CHRO presence, possibly in the more indirect way as suggested by Zhu and Westphal (2014; see footnote 4). It is possible that the relevant aspect is not necessarily the CEOs' or TMTs' HRM experience, measured by the years served in this functional domain, but rather their openness and affinity for the HR aspects of the business (Groysberg et al. 2011). This presumption should be tested in the future through personal interviews or questionnaires, as related psychological attitudes cannot be measured by objective data. We are, however, aware of the difficulty in gaining access to TMT members.

In addition, our study only focused on US firms, which are dominated by a corporate governance system that considers shareholder value as the cornerstone of corporate performance, implying that CFOs have risen within the TMT and are now second to the CEOs (Zorn 2004). Given this, other TMT positions, such as the CHRO, have a less important role for US firms. Studies by scholars such as Farndale and Paauwe (2007) and Pudelko (2006) show that national institutional drivers help shape HRM systems and practices, indicating the need to study more than intra-firm or industry levels to understand the role of institutional embeddedness in the HRM context. Moreover, since our sample only covered the period between 1998 and 2007, it is possible that the relative weights of TMT positions, including the position of the CHRO, have changed following the 2008 financial crisis (Sparrow et al. 2013). This implies the need for more recent and comprehensive data that allow us to consider the rise and fall of different chief officer positions within TMTs. This perspective also suggests that further research is required using samples that include other countries and reflect the "varieties of capitalism" (Hall and Soskice 2001) and their development at the intersection between financial and human capital. The Cranfield Network on International Human Resource Management (CRANET) studies strategic HRM issues in more than 40 countries, but without a distinctive consideration of the CHRO position (for an overview see Parry et al. 2011). Crossland and Hambrick (2011) investigate differences of managerial discretion across 15 countries, and Doms and zu Knyphausen-Aufseß (2014) present an upper echelon study based on a three-country sample, again without a specific focus on CHROs. Our call for research in this direction might be of special interest for German researchers since the German co-determination act of 1976 makes the establishment of a "labor director" for companies with more than 2000 employees obligatory, suggesting that the CHRO position might be more established in Germany compared to the US. This also presents the possibility that our binary assumption that companies either have or do not have a CHRO position may be too simplistic since single TMT members may have multiple functions. Therefore, this also presents an opportunity for future research. ${ }^{7}$

Finally, the emergence of CHROs goes beyond influencing strategic decisions within particular organizations (Menz 2012). At the macro level, the HR community is establishing its power and influence within industries and the overall economy by placing members in the upper echelons of organizations (cf. Hambrick and Mason

\footnotetext{
${ }^{7}$ We thank an anonymous reviewer for this suggestion.
} 
1984). As stated, there are reasons to believe that this development is related to the development of modern capitalism and how modern technologies (most importantly digital technologies) impact the role of labor and the need for HR qualifications (see, e.g., Brynjolfsson and McAfee 2014). From this point of view, the implications for CHRO research go beyond particular organizations or particular industries. In particular, our hypothesis regarding the impact of knowledge intensity, which may coincide with the increasing technology orientation within modern society, on CHRO presence could not be confirmed in our empirical study. This presents the need for a detailed analysis of knowledge and technology-related aspects on the development of SHRM and the role of CHROs. This would also provide valuable insight into the role of the CHRO, not only important for HR or TMT researchers and practitioners, but also for those with broader interests in the development of our economy and society, particularly in the aftermath of the 2007-2008 financial crisis that, according to historians such as Rödder (2015), significantly impacted the rules of the capitalistic game.

Open Access This article is distributed under the terms of the Creative Commons Attribution 4.0 International License (http://creativecommons.org/licenses/by/4.0/), which permits unrestricted use, distribution, and reproduction in any medium, provided you give appropriate credit to the original author(s) and the source, provide a link to the Creative Commons license, and indicate if changes were made.

\section{References}

Abrahamson, E. 1991. 'Managerial fads and fashions: the diffusion and rejection of innovations'. Academy of Management Review 16: 586-612.

Abt, M., and D. zu Knyphausen-Aufseß. 2010. 'Do chief human resource officers influence firm performance?' Working Paper (available from the authors upon request).

Adams, R., B.E. Hermalin, and M.S. Weisbach. 2010. The role of boards of directors in corporate governance: a conceptual framework and survey. Journal of Economic Literature 48: 58-107.

Aijala, A., B. Walsh, and J. Schwartz. 2007. 'Aligned at the Top'. http://www.deloitte.com/dtt/cda/doc/ content/dtt_consulting_aligned052307(1).pdf. Accessed 10 Sept 2009.

Angwin, D., S. Paroutis, and S. Mitson. 2009. Connecting up strategy: are senior strategy directors the missing link? California Management Review 51(3): 74-94.

Baron, J.N., and M.T. Hannan. 2002. Organizational blueprints for success in high-tech start-ups: lessons from the stanford project on emerging companies. California Management Review 44(Spring): $8-36$.

Beaumont, P., and J. Leopold. 1985. Public sector industrial relations: recent developments. Employee Relations 7(4): 1-44

Becker, G.S. 1975. Human Capital. New York: Columbia University Press.

Beckmann, C., and D. Burton. 2011. Bringing organizational demography back in: time, change, and structure in top management team research. In Handbook of research on top management teams, ed. M. Carpenter, 49-72. Cheltenham: Edward Elgar.

Bennett, N., D.J. Ketchen, and E.B. Schulz. 1998. An examination of factors associated with the integration of human resource management and strategic decision-making. Human Resource Management 37: 3-16.

Björkman, I., and P.N. Gooderham. 2012. International human resource management research and institutional theory. In Handbook of research in international human resource management, ed. G.K. Stahl, I. Björkman, and S. Morris, 472-490. Chaltenham et al: Edward Elgar Publishing.

Blanchflower, D.G. 2007. International patterns of union membership. British Journal of Industrial Relations 45: 1-28. 
Boselie, P., and J. Paauwe. 2005. Human resource function competencies in European companies. Personnel Review 34: 550-566.

Bottger, P., and P. Vanderbroeck. 2008. The chief human resources officer: delivering people who can deliver. In Leading in the top team: The CXO challenge, ed. P. Bottger, 223-246. Cambridge: Cambridge University Press.

Boyd, B.K., K.T. Haynes, M.A. Hitt, D.D. Bergh, and D.J. Ketchen. 2012. Contingency hypotheses in strategic management research: use, disuse, or misuse? Journal of Management 38: 278-313.

Brewster, C. 1994. The integration of human resource management and corporate strategy. In Policy and practice in European human resource management, ed. C. Brewster, and A. Hegewisch, 22-35. London: Routledge.

Brynjolfsson, E., and A. McAfee. 2014. The second machine age: work, progress, and prosperity in a time of brilliant technologies. New York: W.W. Norton and Company.

Budhwar, P.S. 2000. Evaluating levels of strategic integration and devolvement of human resource management in the UK. Personnel Review 29: 141-161.

Cai, J., J.L. Garner, and R.A. Wakling. 2009. Electing directors. The Journal of Finance 64: 2389-2421.

Cannella, A.A., and M. Lubatkin. 1993. Succession as sociopolitival process: internal impediments to outsider selection. Academy of Management Journal 36: 763-793.

Caldwell, R. 2003. The changing roles of personell managers: old ambiguities, new uncertainties. Journal of Management Studies 40: 983-1004.

Carpenter, M.A., M.A. Geletkanycz, and W.G. Sanders. 2004. Upper echelons research revisited: antecedents, elements, and consequences of top management team composition. Journal of Management 30: 749-778.

Challah, S. 2006. 'Strategist and steward: the evolving role of the chief human resources officer. http:// www.deloitte.com/view/en_US/us/Services/consulting/human-capital/ 59781ec6f6001210VgnVCM100000ba42f00aRCRD.htm. Accessed 11 Sept 2011.

Chandler, A. 1990. Scale and scope: the dynamics of industrial capitalism. Boston MA: Harvard University Press.

Charan, R., D. Barton, and D. Carrey. 2015. People before strategy: a new role for the CHRO. Harvard Business Review 93(4): 62-71.

Child, J. 1975. Managerial and organizational factors associated with company performance-part II. a contingency analysis. Journal of Management Studies 12: 12-27.

Clune, R., D.R. Hermanson, J.G. Tomkins, and Z. Ye. 2014. 'The nominating committee process: a qualitative examination of board independence and formalization'. Contemporary Accounting Research 31: 748-786.

Coff, R. 2003. Bidding wars over R\&D-intensive firms: knowledge, opportunism, and the market for corporate control. Academy of Management Journal 46: 74-85.

Coles, J.L., N.D. Daniel, and L. Naveen. 2014. Co-opted Boards. Review of Financial Studies 27: 1751-1796.

Craver, C.B. 1997. Mandatory worker participation is required in a declining union environment to provide employees with meaningful industrial democracy. George Washington Law Review 66: $1-62$.

Crossland, C., and D. Hambrick. 2011. Differences in managerial discretion across countries: how nationlevel institutions affect the degree to which CEOs matter. Strategic Management Journal 32: 797-819.

Datta, D.K., J.P. Guthrie, D. Basuil, and A. Pandey. 2010. Causes and effects of employee downsizing: a review and synthesis. Journal of Management 36: 281-348.

Davis, G.F. 2009a. Managed by the markets: how finance re-shaped America. New York: Oxford University Press.

Davis, G.F. 2009b. The rise and fall of finance and the end of the society of organizations. Academy of Management Perspective 23(3): 27-44.

DiMaggio, P.J., and W.W. Powell. 1983. The iron cage revisited: institutional isomorphism and collective rationality in organizational fields. American Sociological Review 48: 147-160.

Dobbin, F., and J. R. Sutton. 1998. The strength of a weak state: the rights revolution and the rise of human resources management divisions. American Journal of Sociology 104: 441-476.

Dobbin, F., and D. Zorn. 2005. Corporate malfeasance and the myth of shareholder value. Political Power and Social Theory 17: 179-198. 
Doms, M., and D. zu Knyphausen-Aufseß. 2014. Structure and characteristics of top management teams as antecedents of outside executive appointments: a three-country study. The International Journal of Human Resource Management 25: 3060-3085.

Donaldson, L. 2001. The contingency theory of organizations. Thousand Oaks: Sage Publications.

Donkin, R. 1999. 'Still struggling for a strategic role'. Financial Times (UK), 25 June 1999.

Dore, R. 2008. Financialization of the global economy. Industrial and Corporate Change 6: 1097-1112.

Eilbirt, 1959. 'The development of personnel management in the United States'. Business History Review 33: 345-364.

Faber, H. 2005. 'Union membership in the United States: the divergence between the public and private sectors'. Princeton University working paper \#503. https://core.ac.uk/download/files/153/6894934. pdf. Accessed 20 May 2016.

Farndale, E., and J. Paauwe. 2007. Uncovering competitive and institutional drivers of HRM practices in multinational corporations. Human Resource Management Journal 17: 355-375.

Finegold, D., and S. Frenkel. 2006. Managing people where people really matter: the management of human resources in biotech companies. International Journal of Human Resource Management 17: $1-24$.

Finkelstein, S. 1992. Power in top management teams: dimensions, measurement, and validation. Academy of Management Journal 35: 505-538.

Finkelstein, S., D.C. Hambrick, and A.A. Cannella. 2009. Strategic leadership: theory and research on executives, top management teams, and boards. Oxford: Oxford University Press.

Fligstein, N. 1987. The intraorganizational power struggle: rise of finance personnel to top leadership in large corporations, 1919-1979. American Sociological Review 52: 44-58.

Galang, M.C., and G.R. Ferris. 1997. Human resource department power and influence through symbolic action. Human Relations 50: 1403-1426.

Galpin, T. 1996. The human side of change: a practical guide to organization redesign. San Francisco: Jossey-Bass.

Greer, C. R., S. A. Youngblood, and D. A. Gray. 1999. Human resource management outsourcing: the make or buy decision. Academy of Management Executive 13(1): 85-96.

Groysberg, B., L.K. Kelly, and B. MacDonald. 2011. The new path to the C-suite. Harvard Business Review 89(3): 60-68.

Hailey, V.H., E. Farndale, and C. Truss. 2005. 'The HR department's role in organisational performance'. Human Resource Management Journal 15: 49-66.

Hall, B.H., and J. Mairesse. 2006. Empirical studies of innovation in the knowledge-driven economy. Economics of Innovation and New Technology 15: 289-299.

Hall, P.A., and D. Soskice. 2001. Varieties of capitalism: the institutional foundations of comparative advantage. Oxford: Oxford University Press.

Hambrick, D.C. 2007. Upper echelons theory: an update. Academy of Management Review 32: 334-343.

Hambrick, D.C., and A.A. Cannella Jr. 2004. CEOs who have COOs: contingency analysis of an explored structural form. Strategic Management Journal 25: 959-979.

Hambrick, D.C., and G.D.S. Fukutomi. 1991. The seasons of a CEO's tenure. Academy of Management Review 16: 719-742.

Hambrick, D.C., and P.A. Mason. 1984. Upper echelons: the organization as a reflection of its top managers. Academy of Management Review 9: 193-206.

Hambrick, R.C., M.A. Geletkanycz, and J.W. Fredrickson. 1993. Top executive commitment to the status quo: some tests of its determinants. Strategic Management Journal 14: 401-418.

Hannan, M.T., J.N. Baron, G. Hsu, and O. Kocak. 2006. 'Organizational identities and the hazard of change'. Industrial and Corporate Change 15: 755-784.

Hannan, M.T., and J.H. Freeman. 1977. The population ecology of organizations. American Journal of Sociology 82: 929-964.

Hannan, M.T., and J.H. Freeman. 1984. Structural inertia and organizational change. American Sociological Review 49: 149-164.

Hermalin, B. E., and M. S. Weisbach. 2003. 'Boards of directors as an endogenously determined institution: a survey of the economic literature. 'Economic Policy Review, Federal Reserve Bank of New York, April 7-26.

Hesse-Biber, S., and R.B. Johnson (eds.). 2015. Oxford handbook of multimethod and mixed methods research inquiry. New York: Oxford University Press.

Heugens, P.M.A.R., and M.W. Lander. 2009. Structure! agency! (and other quarrels): a meta-analysis of institutional theories of organization. Academy of Management Journal 52: 61-85. 
Hislop, D. 2003. Linking human resource management and knowledge management via commitment: a review and a research agenda. Employee Relations 25: 182-202.

Hofstede, G. 1980. Motivation, leadership, and organization: do American theories apply abroad? Organization Dynamics 9(1): 42-63.

Homberg, F., and H.T.M. Bui. 2013. Top management team diversity: a systematic review. Group and Organization Management 38: 455-479.

Horwitz, S.K., and I.B. Horwitz. 2007. The effects of team diversity on team outcomes: a meta-analytic review of team demography. Journal of Management 33: 987-1015.

Huselid, M.A. 1995. 'The impact of human resource management practices on turnover, productivity, and corporate financial performance'. Academy of Management Journal 38: 635-672.

Hwang, B., and S. Kim. 2009. It pays to have friends. Journal of Financial Economics 93: 138-158.

Jackson, S.E., and R.S. Schuler (eds.). 1999. Strategic human resource management. Cornwell: MPG Books.

Jacoby, S. M., E. M. Nason, and K. Saguchi. 2005. The role of the senior HR executive in Japan and the United States: employment relations, corporate governance, and values. Industrial Relations 44: 207-241.

Jarzabkowski, P., and A.P. Spee. 2009. Strategy-as-practice: a review and future directions for the field. International Journal of Management Reviews 11: 69-95.

Josephson, M., and B. Reinken. 2008. The CEO worked where? Putting human resources in the leader's path to the top. Amsterdam: Egon Zehnder International.

Kabst, R. and A. Giardini. 2009. 'Die deutsche Cranet-Erhebung 2005: Empirische Befunde und Ergebnisbericht'[The German Cranet Survey 2005: Empirical findings and final report]. In: 'International komparatives Personalmanagement: Evidenz, Methodik \& Klassiker des "Cranfield Projects on International Human Resource Management", ed. R. Kabst, 11-57. München: Mering.

Kasworm, C. 2011. The influence of the knowledge society: trends in adult higher education. Journal of Continuing Higher Education 59: 104-107.

Kaufman, B. E. 2008. Managing the human factor: the early years of human resource management in American industry. Ithaca: ILR Press.

Kelly, J., and J. Gennard. 2001. Power and influence in the boardroom: the role of the personnel/HR director. New York: Routledge.

Kelly, J., and J. Gennard. 2002. Top guns. People Management 8: 24.

Kivimäki, M., J. Vahtera, J. Pentti, L. Thomson, A. Griffiths, and T. Cox. 2001. Downsizing, changes in work, and self-rated health of employees: a 7-year 3-wave panel study. Anxiety, Stress and Coping: An International Journal 14: 59-73.

Klepper, S. 1997. Industry life cycles. Industrial and Corporate Change 6: 145-182.

Kochan, T. A., and T. A. Barocci. 1985. Human resource management and industrial relations: text, readings, and cases. Boston: Little Brown and Co.

Kostova, T., N. Athanassiou, and I. Berdrow. 2004. Managing knowledge in global organizations. In The Blackwell handbook of global management: a guide to managing complexity, ed. H.W. Lane, M.L. Maznevski, M.E. Mendenhall, and J. McNett, 275-288. Malden: Blackwell.

Kotter, J. 1995. 'Leading change: why transformation efforts fail'. Harvard Business Review 73(2): 59-67.

Lazarsfeld, P.F., and R.K. Merton. 1954. Friendship as a social process: a substantive and methodological analysis. In Freedom and control in modern society, ed. M. Berger, 18-88. New York: Van Nostrand.

Lengnick-Hall, M. L., and C. A. Lengnick-Hall. 2002. Human resource management in the knowledge economy: new challenges, new roles, new capabilities. San Francisco: Berrett-Koehler.

Leydesdorff, L., W. Dolfsma, and G. van der Panne. 2006. Measuring the knowledge base of an economy in terms of triple-helix relations among "technology, organization, and territory". Research Policy 35: 181-199.

Mansfield, E.R., and B.P. Helms. 1982. Detecting multicollinearity. American Statistician 36: 158-160.

Marcel, J.J. 2009. Why top management team characteristics matter when employing a chief operating officer: a strategic contingency perspective. Strategic Management Journal 30: 647-658.

Maritan, C.A., and M.A. Peteraf. 2008. Frontiers of strategic management research: introduction into the special issue. Managerial and Decision Economics 29: 71-77.

Marsden, P.V. 1987. Core discussion networks of Americans. American Sociological Review 52: $122-313$. 
McCroskey, J.C., P.R. Hamilton, and A.N. Weiner. 1974. The effect of interaction behavior on source credibility, homophily, and interpersonal attraction. Human Communication Research 1: 42-52.

McDonald, M.L., and J.D. Westphal. 2003. Getting by with the advice of their friends: CEOs' advice networks and firms' strategic responses to poor performance. Administrative Science Quarterly 48: $1-32$.

McGahan, A.M., and M.E. Porter. 2002. What do we know about variance in accounting profitability? Management Science 48: 834-851.

McPherson, M., L. Smith-Lovin, and J.M. Cook. 2001. Birds of a feather: homophily in social networks. Annual Review of Sociology 27: 415-444.

Mello, J.A. 2015. Strategic human resource management, 4th ed. Stamford: Centage Learning.

Menz, M. 2012. Functional top management team members: a review, synthesis, and research agenda. Journal of Management 38: 45-80.

Menz, M., and C. Scheef. 2014. Chief strategy officers: contingency analysis of their presence in top management teams. Strategic Management Journal 35: 461-471.

Meyer, J.W., and B. Rowan. 1977. Institutionalized organizations: formal structure as myth and ceremony. American Journal of Sociology 83: 340-363.

Miller, C.C., N.T. Washburn, and W.H. Glick. 2013. 'The myth of firm performance'. Organization Science 24: 948-964.

Montoya, R.M., and R.S. Horton. 2013. A meta-analytic investigation of the processes underlying the similarity-attraction effect. Journal of Personal and Social Relationships 30: 64-94.

Nath, P., and V. Mahajan. 2008. Chief marketing officers: a study of their presence in firms' top management teams. Journal of Marketing 72: 65-81.

Neal, D. 1995. Industry specific human capital: evidence from displaced workers'. Journal of Labor Economics 13: 653-677.

OECD. 2001. Science and technology indicators: No 2: R\&D, innovation and competitiveness. Paris.

Okhuysen, G., and J.P. Bonardi. 2011. Editors' comments: the challenges of building theory by combining lenses. Academy of Management Review 36: 6-11.

Paauwe, J., and P. Boselie. 2003. Challenging "strategic HRM" and the relevance of the institutional setting. Human Resource Management Journal 13: 56-70.

Parry, E., E. Stavrou-Costea, and M. Morley. 2011. The Cranet international research network on human resource management in retrospect and prospect. Human Resource Management Review 21: 1-4.

Pfeffer, J. 1998. The human equation. Building profits by putting people first. Boston: Harvard Business School Press.

Phelps, R., R. Adams, and J. Bessant. 2007. 'Life cycles of growing organizations: a review with implications for knowledge and learning'. International Journal of Management Reviews 9: 1-30.

Pudelko, M. 2006. A comparison of HRM systems in the USA, Japan and Germany in their socioeconomic context. Human Resource Management Journal 16: 123-153.

Preston, D.S., D. Chen, and D.E. Leidner. 2008. Examining the antecedents and consequences of CIO strategic decision-making authority: an empirical study. Decision Science 39: 605-642.

Quigley, T.J., and D.C. Hambrick. 2015. Has the "CEO effect" increased in recent decades? A new explanation for the great rise in America's attention to corporate leaders. Strategic Management Journal 36: 821-830.

Ritzer, G. H., and H. Trice. 1969. An occupation in conflict: a study of the personnel manager. Ithaca: ILR Press.

Rödder, A. 2015. 21.0. Eine kurze Geschichte der Gegenwart [21.0. A brief history of the present]. Munich: C. H. Beck.

Ruef, M., H.E. Aldrich, and N.M. Carter. 2003. The structure of founding teams: homophily, strong ties and isolation among US entrepreneurs. American Sociological Review 68: 195-222.

Schoonhoven, C.B. 1981. Problems with contingency theory: testing assumptions hidden within the language of contingency theory. Administrative Science Quarterly 26: 349-377.

Schreyögg, G. 1980. Contingency and choice in organization theory. Organization Studies 1: 305-326.

Shivdasani, A., and D. Yermack. 1999. CEO involvement in the selection of new board members: an empirical analysis. The Journal of Finance 54: 1829-1853.

Sparrow, P., E. Farndale, and H. Scullion. 2013. 'An empirical study of the role of the corporate HR function in global talent management in professional and financial service firms in the global financial crisis'. The International Journal of Human Resource Management 24: 1777-1798.

Storey, J. 1992. Developments in the management of human resources. Oxford: Blackwell. 
Strand, R. 2013. The chief officer of corporate social responsibility: a study of its presence in top management teams. Journal of Business Ethics 112: 721-734.

Sydow, J., G. Schreyögg, and J. Koch. 2009. 'Organizational path dependence: opening the black box'. Academy of Management Review 34: 689-709.

Tattersall, A. 2010. Power in coalition. Strategies for strong unions and social change. Ithaca: Cornell University Press.

Tsui, A.S., T.D. Egan, and C.A. O’Reilly III. 1992. Being different: relational demography and organizational attachment. Administrative Science Quarterly 37: 549-579.

Tuttle, B., and J. Dillard. 2007. Beyond competition: institutional isomorphism in US accounting research. Accounting Horizons 21: 387-409.

Ulrich, D. W., and D. Brockband. 2005. The HR value proposition. Boston: Harvard Business School Press.

Ulrich, D., J. Younger, W. Brockband, and M. Ulrich. 2012. HR from the outside in. six competencies for the future of human resources. New York: McGraw-Hill.

Van Elteren, M. 2006. Americanism and Americanization. A Critical History of Domestic and Global Influence. Jefferson: McFarland \& Company.

Verbrugge, L.M. 1983. A research note on adult friendship contact. Social Forces 62: 78-83.

Welbourne, T.M., and L.A. Cyr. 1999. The human resource executive in effect in initial public offering firms. Academy of Management Journal 42: 616-629.

Welbourne, T.M., and A.O. Andrews. 1996. Predicting the performance of initial public offerings: should human resource management be in the equation? Academy of Management Journal 39: 891-919.

Welch, J., and S. Welch. 2005. Winning. New York: Harper Business.

Wright, P. M., P. McKinnon, R. L. Antoine, E. Sartain, J. W. Boudreau, and D. A. Pace. 2011. 'The evolving chief human resources officer role'. In The chief HR officer. Defining the new role of human resource leaders, eds. P. M. Wright, J. W. Boudreau, D. A. Pace, E. Sartain, P. McKinnon, and R. L. Antoine, 1-11. San Francisco: Jossey Bass.

Zeger, S.L., and K.-Y. Liang. 1986a. Longitudinal data analysis using generalized linear models. Biometrika 73: 13-22.

Zeger, S.L., and K.-Y. Liang. 1986b. Longitudinal data analysis for discrete and continuous outcomes. Biometrics 42: 121-130.

Zhang, Y. 2006. The presence of a separate COO/president and its impact on strategic change and CEO dismissal. Strategic Management Journal 27: 283-300.

Zhu, D.H., and J.D. Westphal. 2014. 'How directors' prior experience with other demographically similar CEOs affects their appointments to corporate boards and the consequences for CEO compensation'. Academy of Management Journal 57: 791-813.

Zorn, D.M. 2004. Here a chief, there a chief: the rise of the CFO in the American firm. American Sociological Review 69: 345-364. 